\title{
PRODUCTIVITY AND BLOOD BIOCHEMICHAL CHANGES IN RABBITS FED MORINGA OLEIFERA LEAVES MEAL AS AN UNTRADITIONAL SOURCE OF PROTEIN UNDER NORTH SINAI CONDITIONS
}

\author{
E. O. A. Bakr, A. M. Abdel-Samee and M. M. Shetaewi \\ Animal and Poultry Production Department, Faculty of Environmental Agricultural Sciences, Arish \\ University, North Sinai, Egypt.
}

(Received 10/2 /2019, Accepted 25 /3 /2019)

\section{SUMMARY}

$\mathrm{T}$ The study aimed to evaluate the effect of feeding Moringa oleifera leaves meal (MOLM) on productivity of growing rabbits and some related blood changes. Forty five weaned New Zealand White rabbits of both sexes aged 6 weeks and weighted $800 \pm 39 \mathrm{~g}$ were randomly divided into three groups (15 each). Rabbits were fed diets containing $0 \%, 3 \%$ and 6\% MOLM as substitute of alfalfa hay and soybean meal at $(2: 1)$ as $\mathrm{T} 0, \mathrm{~T} 3$ and $\mathrm{T} 6$, respectively. The experimental diets were iso-nitrogenous (16.2 $\% \mathrm{CP}$ ) and iso-caloric $(2530 \mathrm{kcal} \mathrm{DE} / \mathrm{kg}$ diet). All the experimental diets were formulated to cover the nutrient requirements of rabbits. The experimental diets and fresh water were supplied ad-libitum throughout the experimental period ( $8 \mathrm{wk}$ ).-Results revealed that inclusion of MOLM in rabbit diets did not significantly affected either feed intake, feed conversion or carcass traits. Albumin and ALT significantly affected due to MOLM feeding. Similarly, Mean corpuscular volume (MCV), mean corpuscular hemoglobin (MCH), platelets counts, white blood cells (WBC), neutrophils and segmented cells were significantly affected by dietary treatment. MCV and $\mathrm{MCH}$ were decreased, however, platelet counts, WBC, neutrophils and segmented cells were increased $(\mathrm{P}<0.05)$ in rabbits fed MOLM diet compared to control. There were no significant differences among dietary treatments in blood hemoglobin $(\mathrm{Hb})$, packed cell volume (PCV), red blood cell (RBCs) mean corpuscular hemoglobin concentrations (MCHC) and basophils. All blood biochemical and hematological parameters were within the normal range for healthy rabbits.-Therefore, it can be concluded that inclusion of Moringa oleifera leaves meal in the diets of weaned New Zealand White rabbits up to $6 \%$ under North Sinai conditions had no adverse effects on its productivity and their blood profile. Moreover, these substitutions had not any bad effects on peripheral sings of health or internal sings, kidney, liver or blood characteristics of NZW rabbits.

Keywords: Rabbits, Moringa oleifera leave meal, growth performances, carcass traits and some blood constituents.

\section{INTRODUCTION}

Rabbits farming plays an essential role in involving the gap between the needs and the production of animal protein in developing countries. Rabbits are characterized by early sexual maturity, high prolificacy, rapid growth rates, high feed efficiency and simple housing requirements. In addition, rabbits have a high ability to feed on a diet containing forages and fibrous by-products (Cheeke, 1986 and AboulEla et al., 2011).

In Egypt, animal feeds are limited on the basis of the competition on limited cultivable land between human foods and animal feeds. Hence, many efforts have been made to find new sources of animal feeds. Moringa oleifera is considered one of the new green forages in Egypt that can be used to help us feeding our animals with less costs without physiological detrimental effects. Moringa oleifera is the most widely cultivated species of the monogeneric family Moringacease which includes 14 known species of trees and shrubs. It is originated in India but it is currently found in most tropical countries (Emongor, 2009 and Kelly, 2009). It is a fast-growing tree that can reach up to 7-12 m. Moringa oleifera is a multifunction plant that can be used for human food, fodder and medicine and water purification. It grows well at altitudes from 0 to $1800 \mathrm{~m}$ above sea level, rainfall between 500 and $1500 \mathrm{~mm}$ per year and tolerate drought up to 6 months of dry season (Makkar and Becker, 1997). It can grow in all types of soil, from acid to alkaline (Duke, 1983). Ahmed (2017) found that yielding of the freshly harvested Moringa plants, 


\section{Bakr et al.}

dried forage and dried leaves were 6.81 to $8.3,1.6$ to 1.8 and 0.14 to 0.16 tons/feddan, respectively at spacing $30 * 60 \mathrm{~cm}$ and harvesting every 45 days.

Moreover, leaves of $M$. oleifera have a high protein content which ranges between 20 and $33 \%$ on dry weight basis and contain all the essential, non-essential and sulphur-amino acids (Foidl and Paull, 2008 and Abdel-Azeem 2017). Moringa leaves have a negligible content of tannins (21-23 gm/ $/ \mathrm{kg})$ in all fraction of the plant, a saponin content similar to that of soybean meal and no trypsin and amylase inhibitors or cyanogenic glucosides (Makker and Becker, 1997). Abdel-Azeem et al., (2017) stated that Moringa oleifera leaves has considerable content of macro and micro-elements, especially iron and selenium and considered excellent source of many vitamins (A, B, C, and E).

Therefore, this study aimed to revision the effects of incorporating Moringa oleifera leave meal as a protein source in the diets of growing rabbits on its growth performances and some blood changes.

\section{MATERIALS AND METHODS}

The experimental work was carried out at the rabbitry farm of the Department of Animal and Poultry Production, Faculty of Environmental Agricultural Sciences, Arish University, North Sinai, Egypt. The experiment continued for 8 wk period starting April $1^{\text {st }}$ till the end of May 2017.

Moringa oleifera leaves (MOL) were harvested at 2 mo of age in a private farm at Kafr Sakr Region, Sharkia governorate, Egypt. Leaves were air dried under shade (about 72 hour) until their moisture content almost reached 10\%. The dry leaves were milled, sieved (1 mm mesh) and stored in a well tight polyethylene bags at room temperature until they were used. Sample of dry Moringa oleifera leaves meal (MOLM) were taken for chemical analysis. MOLM was analyzed for crude protein (CP), crude fiber $(\mathrm{CF})$, ether extract (EE), ash, calcium (Ca) and phosphorus (P) according to A. O. A. C (2012).

Feeding and management: Forty five weaned New Zealand white (NZW) rabbits of both sexes (6 wk old and $800 \mathrm{~g}$ body weight) were used. Rabbits were randomly allocated into 3 dietary treatment groups. The experimental period lasted for 56 days (From 6 to $14 \mathrm{wk}$ of age). The $1^{\text {st }}$ treatment group (control, T0) was fed a pelleted control diet, the $2^{\text {nd }}$ treatment group (T3) was fed a diet containing 3\% MOLM substituting $2 \%$ alfalfa hay and $1 \%$ soybean meal. The $3^{\text {rd }}$ treatment group (T6) was fed a diet containing $6 \%$ MOLM substituting 4\% alfalfa hay and 2\% soybean meal, respectively (Table 1). MOLM was handly mixed with feed ingredients and the experimental diets were pelleted under a temperature of $70 \dot{\mathrm{C}}$ at 0.3 $\mathrm{cm}$ diameter and $2 \mathrm{~cm}$ length. The experimental diets were formulated to be iso-nitrogenous $(\approx 16.2 \mathrm{CP})$, iso-caloric (2530 kcal DE/kg diet) and meet the recommended nutrient requirements of growing rabbits according to Agriculture Ministry Decree (1996).

The composition and calculated analysis of the experimental diets are presented in Table (1). Each three rabbits were housed in a galvanized wire cage measured $(40 * 40 * 30 \mathrm{~cm})$ in a well-ventilated building (natural through the window) and natural light. Cages were provided with feeders and automatic nipple drinkers. The experimental diets and fresh water were supplied ad-libitum twice daily at 8.00 AM and 6.00 PM. All rabbits were kept under the same managerial, hygienic and environmental conditions. Individual BW and feed intake (FI) were determined weekly. Body weight gain and feed conversion ratio (feed/ gain) were calculated.

Carcass traits: At the end of the experimental period (14 wk of age), three rabbits were randomly chosen from each treatment to study carcass traits. Rabbits were kept off feed overnight and body weights were recorded next morning prior to slaughter. After bleeding and skinning were completed, the carcass was opened down and all entrails were removed. The empty carcass with head, head, liver, kidneys and heart were weighed separately (Cheeke, 1987 and Shetaewi, M.M, 1998).

Blood sampling: When rabbits were slaughtered, paired blood samples were collected from each rabbit (3 in each group). The first sample was collected into heparinized tube for hematological studies which determined on the day of collection. The second blood sample was collected into clean non-heparinized tube and allowed to clot at room temperature and then centrifuged at $3000 \mathrm{rpm}$ for 15 minutes and the serum was separated and stored at $-20 \dot{C}$ until analyzing. Serum total protein and glucose were colorimetrically determined using Kits supplied by Bio Merieux, France. Urea and creatinine colorimetrically determined using Kits supplied by Diamond, Egypt. Albumin, ALT and AST were colorimetrically determined using Kits supplied by Randox, England. Serum globulin was obtained by difference (Total protein minus albumin) Cholesterol was colorimetrically determined using Kits supplied by Spectrum, Egypt. 
Table (1): Composition and calculated analysis of the experimental diets.

\begin{tabular}{|c|c|c|c|}
\hline \multirow{2}{*}{ Item } & \multicolumn{3}{|c|}{ Dietary Treatment $^{1}$} \\
\hline & T0 & T3 & T6 \\
\hline \multicolumn{4}{|l|}{ Ingredients: } \\
\hline Alfalfa hay $(15 \% \mathrm{CP})$ & 29 & 27 & 25 \\
\hline Yellow corn & 27.5 & 27.5 & 27.5 \\
\hline Soybean meal (44\% CP) & 14 & 13 & 12 \\
\hline Wheat bran & 25 & 25 & 25 \\
\hline Moringa oleifera leaves meal (MOLM) & - & 3 & 6 \\
\hline Molasses & 2 & 2 & 2 \\
\hline Salt & 0.3 & 0.3 & 0.3 \\
\hline Limestone & 0.6 & 0.6 & 0.6 \\
\hline Vitamins and mineral mixture $^{2}$ & 0.3 & 0.3 & 0.3 \\
\hline Di-calcium phosphate & 1.2 & 1.2 & 1.2 \\
\hline Anti-fungi & 0.1 & 0.1 & 0.1 \\
\hline Total & 100 & 100 & 100 \\
\hline \multicolumn{4}{|l|}{ Calculated analysis ${ }^{3}$ : } \\
\hline Digestible energy $(\mathrm{DE})^{4} \mathrm{kcal} / \mathrm{kg}$ & 2530 & 2540 & 2560 \\
\hline Crude protein $(\mathrm{CP}), \%$ & 16.15 & 16.22 & 16.30 \\
\hline Crude fiber $(\mathrm{CF}), \%$ & 12.74 & 12.41 & 12.07 \\
\hline $\mathrm{NDF}, \%$ & 37.22 & 37.00 & 36.77 \\
\hline Ether extract (EE), \% & 2.92 & 3.04 & 3.17 \\
\hline Calcium (Ca), \% & 0.99 & 1 & 1.02 \\
\hline Available phosphorus & 0.46 & 0.46 & 0.47 \\
\hline Lysine & 0.88 & 0.88 & 0.88 \\
\hline Methionine & 0.3 & 0.3 & 0.3 \\
\hline $\mathrm{DE}: \mathrm{CP}$ & 157.44 & 157.27 & 157.93 \\
\hline \multicolumn{4}{|c|}{ 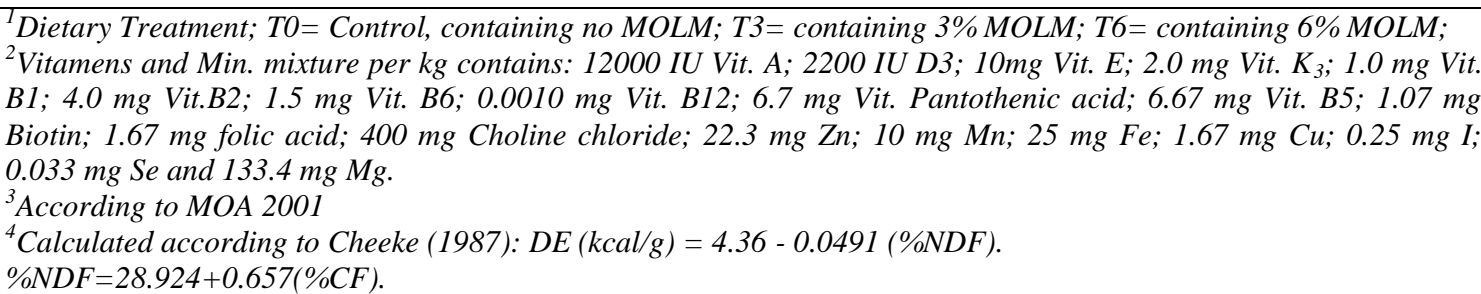 } \\
\hline
\end{tabular}

Blood hemoglobin $(\mathrm{Hb})$ was determined colorimetrically using kits provided by Randox, England. Packed cell volume (PCV \%) was determined according to Wintrobe (1967). Red blood cell (RBCs) count, platelets and total count of white blood cells (WBCs) were determined according to (Dacie and Lewis, 1995). Mean corpuscular values (MCV), mean corpuscular hemoglobin concentration (MCHC) and mean corpuscular hemoglobin $(\mathrm{MCH})$ were calculated from values obtained from RBC count as the following:

$\mathrm{MCV}=(\mathrm{PCV} \% * 10) / \mathrm{RBC} ; \mathrm{MCH}=(\mathrm{Hb} * 10) / \mathrm{RBC}$ and $\mathrm{MCHC}=(\mathrm{Hb} * 100) / \mathrm{PCV} \%$

Economic efficiency: Was calculated as the ratio between incomes price of weight gain and the cost of feed consumed over 6-14 weeks of age.

Statistical analyses: Data were subjected to statistical analysis by the SAS (2004) computer program using the general linear models (GLM). Differences among treatment means were tested using the leastsignificant difference test (Steel and Torrie, 1980).

\section{RESULTS AND DISCUSSION}

Chemical composition of Moringa oleifera leaves: Table (2). showed that MOLM is rich in macro nutrients, where the values of dry matter, organic matter, crude protein, crude fiber, ether extract, nitrogen free extract, ash, Ca, $\mathrm{P}$ and $\mathrm{DE}(\mathrm{kcal} / \mathrm{kg})$ were found to be $89,90.34,29.49,10.01,7.24,43.60,9.66,1.65,0.34 \%$ and $2620 \mathrm{kcal} / \mathrm{kg}$, respectively. Values of $\mathrm{CP} \%, \mathrm{CF} \%$ and $\mathrm{EE} \%$ of MOLM in this study were higher than those reported by (Abo ELAzab, 2015 and Abdel-Azeem et al., 2017). While ash content of MOLM of the present study (9.66\%) is lower than the values 10.53 and $11.97 \%$ which reported by the same authors. 
Table (2): Chemical composition of Moringa oleifera leaves meal (MOLM, as DM \%).

\begin{tabular}{lc}
\hline Item & MOLM $^{*}$ \\
\hline Dry matter (DM), \% & 89 \\
Organic matter (OM), \% & 90.34 \\
Crude protein (CP), \% & 29.49 \\
Crude fiber (CF), \% & 10.01 \\
Ether extract (EE), \% & 7.24 \\
Nitrogen free extract (NFE), \% & 43.60 \\
Ash & 9.66 \\
Neutral detergent fiber (NDF), \% & 35.50 \\
$\mathrm{Ca}, \%$ & 1.65 \\
$\mathrm{P}, \%$ & 0.34 \\
$\mathrm{DE}$ & $(\mathrm{kcal} / \mathrm{kg})$ \\
\hline
\end{tabular}

* MOLM, Moringa oleifera leaves meal

**DE calculated according to Cheeke (1987), DE (kcal/g) $=4.36-0.0491(\% \mathrm{NDF})$,

$\% N D F=28.924+0.657(\% C F)$.

The variations in the values of chemical analysis of MOLM may be attributed to variations in agro-climatic conditions, different stage of maturity (harvesting), type of soil, methods of processing and the analytical techniques used (Fuglie, 1999).

Growth performance: Tables ( 3 and 4 ) showed that live body weight, daily body gain, total feed intake and feed conversion at different ages (6-10, 10-14 and 6-14 weeks of age) did not change significantly as a function of dietary treatments. The mean values of live body weight were improved slightly with increasing MOLM level in rabbit's diets.

Table (3): Live body weight and daily gain of growing rabbits as influenced by dietary treatments.

\begin{tabular}{|c|c|c|c|c|}
\hline \multirow{2}{*}{ Item } & \multicolumn{3}{|c|}{ Treatment $^{1,2}$} & \multirow{2}{*}{ S.E. ${ }^{3}$} \\
\hline & $\mathrm{T}_{0}$ & $\mathrm{~T}_{3}$ & $\mathrm{~T}_{6}$ & \\
\hline \multicolumn{5}{|c|}{ live body weight (g) } \\
\hline 6 wk. & 793.0 & 805.0 & 794.7 & 39 \\
\hline $10 \mathrm{wk}$. & 1584.8 & 1658.8 & 1610.1 & 53 \\
\hline 14 wk. & 2090.1 & 2127.5 & 2162.4 & 56 \\
\hline \multicolumn{5}{|c|}{ Daily weight gain (g) } \\
\hline $6-10 \mathrm{wk}$. & 29.2 & 30.3 & 28.9 & 1.2 \\
\hline 10-14 wk. & 17.8 & 16.9 & 19.6 & 1.9 \\
\hline 6-14 wk. & 23.6 & 23.6 & 24.3 & 1.06 \\
\hline No. of dead rabbits & 4 & 2 & 1 & \\
\hline Mortality rate & 26.67 & 13.33 & 6.67 & \\
\hline
\end{tabular}

The slightly improvement of growth performance which resulted from inclusion of MOLM in rabbit diets could be attributed to the high content and quality of protein (especially the essential amino acids), vitamins A, B, C and E, and minerals especially $\mathrm{Ca}, \mathrm{K}, \mathrm{Fe}$ and $\mathrm{Se}$ besides the bio-active components such as glycosides, tannins, flavonoids, saponins and alkaloids (Odeyinka et al., 2008 and Abdel-Azeem et al., 2017).

Mortality rate decreased gradually with increasing the MOLM level in rabbit's diet (Table 3). This may be due to the presence of antioxidants in Moringa leaves which enhances the immune system of animals (Yang et al., 2006). In the same trend, DU et al., (2007) found that dietary supplementation of M. oleifera improved immune ability of broilers. These results agree with these obtained by Bouatene et al., (2011) who found that supplementation of $M$. oleifera leaf meal at $3 \%$ improved survival rate in growing rabbit. 
Table (4): Total feed intake and feed conversion ratio as influenced by dietary treatments.

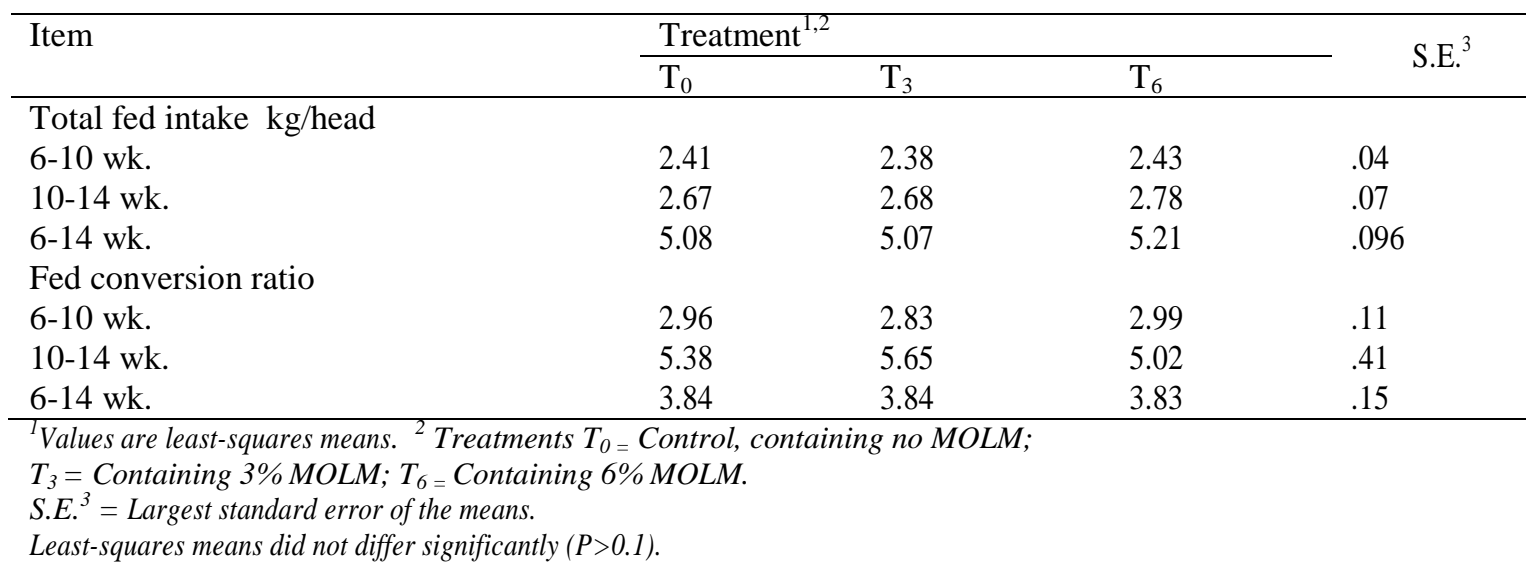

Carcass traits: As shown in Table (5), empty carcass and total edible parts weights of rabbits fed the diet containing 6\% MOLM (T6) were significantly $(\mathrm{P}<0.05)$ higher than those fed control diet $(0 \%$ MOLM, T0) but did not differ significantly ( $\mathrm{P}>0.05)$ from those fed the diet containing 3\% MOLM (T3). This may be due to the high live body weight of rabbits fed 6\% MOLM than those fed the control or the 3\% MOLM diets. Also, the present results showed no significant difference in liver, Kidney, heart, head weight and dressing percentage among dietary treatments. The present findings agree with those obtained by (Nuhu, 2010 and Abubakar et al., 2015). Internal organs (liver, kidney and heart) appeared normal in size and did not show any signs of toxicity (Table 5). Based on the results of this study, it was concluded that Moringa oleifera leaves meal can be incorporated in the diets of rabbits without any deleterious effects on carcass and organ weights of growing rabbits.

In contrast, Yakubu et al. (2013) found that all carcass traits of growing rabbits fed diets containing MOLM at level 2.5, 5.0, 7.5 and $10 \%$ were significantly $(\mathrm{P}<0.05)$ influenced compared with those fed the control diet. However, rabbits fed 7.5\% MOLM diet had the highest carcass weight and dressing percentage than those fed the other diets.

Table (5): Effect of dietary treatments on carcass characteristics of rabbits>

\begin{tabular}{|c|c|c|c|c|}
\hline \multirow{2}{*}{ Item } & \multicolumn{3}{|c|}{ Treatment $^{1,2}$} & \multirow{2}{*}{ S.E. ${ }^{3}$} \\
\hline & $\mathrm{T}_{0}$ & $\mathrm{~T}_{3}$ & $\mathrm{~T}_{6}$ & \\
\hline Pre-slaughter wt. (kg) & $2.226^{\mathrm{a}}$ & $2.269^{\mathrm{ab}}$ & $2.345^{b}$ & .03 \\
\hline Empty carcass wt. (kg) & $1.315^{\mathrm{a}}$ & $1.378^{\mathrm{ab}}$ & $1.430^{b}$ & .03 \\
\hline Total edible parts ${ }^{4}(\mathrm{~kg})$ & $1.402^{\mathrm{a}}$ & $1.460^{\mathrm{ab}}$ & $1.524^{b}$ & .03 \\
\hline Goblets wt. ${ }^{5}(\mathrm{~g})$ & 87.0 & 81.7 & 94.67 & 6.9 \\
\hline Head $(g)$ & 126.3 & 116.0 & 133.7 & 6.4 \\
\hline Liver (g) & 68.0 & 63.7 & 73.7 & 6.4 \\
\hline Kidneys (g) & 13.0 & 12.0 & 14.0 & .75 \\
\hline Heart $(g)$ & 6.0 & 6.0 & 7.0 & .47 \\
\hline Dressing \% & 62.99 & 64.30 & 65.00 & 1.08 \\
\hline \multicolumn{5}{|c|}{${ }^{1}$ Values are least-squares means. ${ }^{2}$ Treatments, $T_{0}=$ Control, containing no MOLM; } \\
\hline \multirow{2}{*}{\multicolumn{5}{|c|}{$\begin{array}{l}T_{3}=\text { Containing } 3 \% \text { MOLM; } T_{6=} \text { Containing } 6 \% \mathrm{MOLM} . \\
{ }^{3} S . E .=\text { Largest standard error of the means. }\end{array}$}} \\
\hline & & & & \\
\hline \multicolumn{5}{|c|}{${ }^{4}$ Total edible parts $w t .=$ empty carcass $w t .($ with head $)+$ edible giblets $w t}$. \\
\hline \multicolumn{5}{|c|}{${ }^{5}$ Edible giblets $w t .=$ Liver + Kidneys $w t .+$ Heart $w t}$. \\
\hline \multicolumn{5}{|c|}{${ }^{a, b}$ Means in the same row with different superscripts differ $(P<0.05)$. } \\
\hline Least-squares means did not c & intly $(P<0$ & & & \\
\hline
\end{tabular}

Blood constituents: Blood biochemical parameters reflect the physiological responsiveness of the animal to its internal and external environments which include feed and feeding. However, they are influenced by quantity and quality of ingested feed and the level of anti- nutritional factors of the feed (Esonu et al., 2001; Iheukwumere and Okoli; 2002 and Akinmutimi, 2004). Data in Table 6 revealed that all blood biochemical parameters (except for albumin and ALT, $\mathrm{P}<0.05)$ did not significantly $(\mathrm{P}>0.05)$ differ due to dietary treatments. Cholesterol tended to decrease $(\mathrm{P}>0.05)$ due to inclusion of MOLM in rabbits' diet. 


\section{Bakr et al.}

This may be attributed to the hypolipidemic effect of bioactive phyto-constituents such as alkaloids and sapanins (Dong et al., 2007). Our findings are in agreement with of Nuhu (2010), Odetola et al., (2012) and Ahmed (2017).

Glucose, total protein and AST showed insignificant increases in $\mathrm{T}_{3}$ and $\mathrm{T}_{6}$ treatment groups. Albumin and ALT were significantly $(\mathrm{P}<0.05)$ increased with increasing MOLM in the diet. T6 having the highest values $(45 \mathrm{mg} / \mathrm{dl}$ and $72.7 \mathrm{u} / \mathrm{l})$ and $\mathrm{T} 0$ had the lowest values $(3.97 \mathrm{mg} / \mathrm{dl}$ and $44.0 \mathrm{u} / \mathrm{l})$ for albumin and ALT, respectively.

The improvement in glucose, total protein and albumin may be attributed to MOLM having various phytochemical and bioactive components such as the trace metals ions, vitamins, alkaloids, carotenoids and polyphenols which enhance rabbit's health in the long-term (Sravanrthi and Rao, 2014).

Increasing serum levels of ALT and AST enzymes may reflect damage of liver cells. These results are in line with those obtained by Adedapo et al. (2009) who found that AST and ALT of rats were significantly $(\mathrm{P}<0.05)$ increased when rats were treated with $(400 \mathrm{mg} / \mathrm{kg}$ and $1600 \mathrm{mg} / \mathrm{kg}) \mathrm{MOLM}$ extract compared with untreated rates. This may be linked to the presence of phenolic compounds and saponins in MOLM. Abo-Zaid et al. (1993) reported that rats injected with phenolic compounds showed significantly higher values in liver enzymes (AST and ALT) compared with untreated ones.

In contrast, Omara et al., (2017) found that total protein, albumin, globulin and cholesterol were significantly affected by inclusion of MDL in rabbit's diet while ALT and AST were not significantly affected by MDL supplement.

Table (6): Serum biochemical parameters of rabbits as influenced by dietary treatments.

\begin{tabular}{lcccc}
\hline Constituent & \multicolumn{3}{c}{ Treatment $^{1,2}$} & \multirow{2}{*}{ S.E. $^{3}$} \\
\cline { 2 - 4 } & $\mathrm{T}_{0}$ & $\mathrm{~T}_{3}$ & $\mathrm{~T}_{6}$ & 11 \\
Glucose $(\mathrm{mg} / \mathrm{dl})$ & 108 & 125 & 123 & .34 \\
Total protein $(\mathrm{g} / \mathrm{dl})$ & 6.50 & 6.60 & 6.97 & .16 \\
Albumin $(\mathrm{g} / \mathrm{dl})$ & $3.97^{\mathrm{a}}$ & $4.33^{\mathrm{ab}}$ & $4.50^{\mathrm{b}}$ & .24 \\
Globulin $(\mathrm{g} / \mathrm{dl})$ & 2.53 & 2.27 & 2.47 & 7.1 \\
Cholesterol (mg/dl) & 40.0 & 35.0 & 38.0 & 1.69 \\
Urea nitrogen (mg/dl) & 40.7 & 39.3 & 43.0 & .13 \\
Creatinine (mg/dl) & 1.73 & 1.61 & 1.56 & 7.7 \\
ALT $(\mathrm{u} / \mathrm{l})$ & $44.0^{\mathrm{a}}$ & $57.0^{\mathrm{ab}}$ & $72.7^{\mathrm{b}}$ & 6.7 \\
AST (u/l) & 48.7 & 51.7 & 53.0 & \\
\hline
\end{tabular}

${ }^{\text {I}}$ Values are least-squares means. ${ }^{2}$ Treatments, $T_{0}$ Control, containing no MOLM;

$T_{3}=$ Containing 3\% MOLM; $T_{6}=$ Containing 6\% MOLM.

${ }^{3}$ S.E. $=$ Largest standard error of the means.

${ }^{a, b}$ Means in the same row with different superscripts differ $(P<0.05)$.

Hematological parameters are valuable in monitoring feed toxicity especially with feed components that affect the formation of blood (Oyawoye and Ogukunle, 1998 and Akinmutimi, 2004). Data in Table 7 showed no significant differences in hemoglobin $(\mathrm{Hb})$, packed cell volume (PCV), red blood cells (RBCs) and mean corpuscular hemoglobin concentration (MCHC) among dietary treatments. Mean corpuscular hemoglobin $(\mathrm{MCH})$ and mean corpuscular volume $(\mathrm{MCV})$ were significantly $(\mathrm{P}<0.05)$ decreased by incorporating MOLM in rabbits' diets compared with 0\% MOLM diet. There were insignificant increases in $\mathrm{Hb}, \mathrm{PCV}, \mathrm{RBCs}$ and $\mathrm{MCHC}$ of rabbits fed diets containing MOLM compared with those fed MOLM free diet. This indicates that M. oleifera proteins are of higher quality (Ahemen et al., 2013). Lymphocytes, Monocytes, eosinophil's and basophils were not significantly $(\mathrm{P}>0.05)$ affected by dietary treatments. While, platelets count, white blood cells (WBCs), neutrophils and segment cells were significantly $(\mathrm{P}<0.05)$ affected by dietary treatments. High WBC count is usually associated with microbial infection due to the presence of foreign bodies or antigens in the circulating system (Oyawoye and Ogunkunle, 1998). Similarly, Ozovehe and Nzeh (2013), reported that WBCs count were significantly $(\mathrm{P}<0.05)$ increased as $M$. oleifera increased in fish diet and could be attributed to toxicity. The WBC counts and its differentials were in normal range of healthy rabbits (Hewitt et al 1989 and Thrall et al., 2012). It implies that the immune system of rabbits fed MOLM diets was in normal condition. 
Table (7): Blood picture of rabbits as influenced by dietary treatments.

\begin{tabular}{lcccc}
\hline \multirow{2}{*}{ Item } & \multicolumn{3}{c}{ Treatment } & \multirow{2}{*}{ S.E. $^{3}$} \\
\cline { 2 - 3 } & $\mathrm{T}_{0}$ & $\mathrm{~T}_{3}$ & $\mathrm{~T}_{6}$ & .38 \\
$\mathrm{Hb}(\mathrm{g} / \mathrm{dl})$ & 12.8 & 12.3 & 13.2 & 1.35 \\
$\mathrm{PCV}(\%)$ & 41.7 & 39.9 & 41.9 & .19 \\
RBC'S $\left(\times 10^{6} / \mu \mathrm{L}\right)$ & 6.06 & 6.24 & 6.48 & 1.4 \\
$\mathrm{MCV}(\mathrm{fl})$ & $69.1^{\mathrm{a}}$ & $64.0^{\mathrm{b}}$ & $64.8^{\mathrm{b}}$ & .35 \\
$\mathrm{MCH}(\mathrm{pg})$ & $21.1^{\mathrm{a}}$ & $19.8^{\mathrm{b}}$ & $20.4^{\mathrm{ab}}$ & .48 \\
MCHC $(\%)$ & 30.5 & 30.9 & 31.6 & 1.02 \\
RDW-CV $(\%)$ & 15.7 & 15.2 & 16.2 & 45 \\
Platelets count $(\times 103 / \mu \mathrm{L})$ & $255^{\mathrm{a}}$ & $328^{\mathrm{a}}$ & $483^{\mathrm{b}}$ & .69 \\
WBCs $(\times 103 / \mu \mathrm{L})$ & $5.97^{\mathrm{a}}$ & $9.83^{\mathrm{b}}$ & $8.60^{\mathrm{b}}$ & 4.4 \\
NEUTRO \% & $29.0^{\mathrm{a}}$ & $38.9^{\mathrm{b}}$ & $32.8^{\mathrm{b}}$ & 0.0 \\
STAFF \% & 4.0 & 4.0 & 4.0 & 4.5 \\
SEGM \% & $25.1^{\mathrm{a}}$ & $35.1^{\mathrm{b}}$ & $29.0^{\mathrm{b}}$ & 5.1 \\
LYMPHO \% & 63.1 & 52.4 & 57.7 & .93 \\
MONO \% & 6.4 & 6.2 & 7.6 & .83 \\
EOSINO \% & 0.40 & 1.5 & 1.4 & .36 \\
BASO \% & 1.0 & 1.0 & .5 & .36 \\
\hline
\end{tabular}

${ }^{1}$ Values are least-squares means. ${ }^{2}$ Treatments, $T_{0=}$ Control, containing no MOLM;

$T_{3}=$ Containing 3\% MOLM; $T_{6=}$ Containing 6\% MOLM.

S.E. ${ }^{3}=$ Largest standard error of the means.

${ }^{a, b}$ Means in the same row with different superscripts differ $(P<0.05)$.

Values of blood biochemical and hematological parameters in these studies were within the normal range of healthy rabbits (Manning et al., 1994; Hewitt et al., 1989 and Thrall et al., 2012). This implies that nutrients and dietary protein of MOLM were adequate and well utilized by the rabbits.

Economic efficiency: Table (8) shows the economic evaluation of feeding growing rabbits on varying levels of MOLM supplement. The present results revealed that total feed cost / rabbit, total revenue/ weight gain, net revenue/ rabbit (L.E), economic efficiency (EE, \%) and relative economic efficiency (R.EE, \%) were almost similar in the different dietary treatments. This was attributed to the fact that the price of one $\mathrm{kg}$ of MOLM equal the price of one $\mathrm{kg}$ of a mixture of alfalfa hay and soybean meal at 2:1 ratio. Total feed intake and total weight gain were similar in the different dietary treatments. Economic efficiency followed the same trend.

Table (8):Economic efficiency as affected by Moringa oleifera leaves meal (MOLM) in rabbits' diet.

\begin{tabular}{lccc}
\hline \multirow{2}{*}{ Item } & \multicolumn{3}{c}{ Dietary Treatment $^{*}$} \\
\cline { 2 - 4 } & T0 & T3 & T6 \\
\hline Price/kg diet** & 4.60 & 4.59 & 4.58 \\
Total feed intake/rabbit (g) & 5080 & 5070 & 5210 \\
Total feed cost/rabbit (L.E) & 23.37 & 23.27 & 23.86 \\
Total weight gain/rabbit (g) & 1312.91 & 1321 & 1360.64 \\
Feed cost/kg gain & 17.69 & 17.61 & 17.54 \\
Price/kg weight gain (L.E) & 30 & 30 & 30 \\
Total revenue/weight gain (L.E) & 39.63 & 39.63 & 40.8 \\
Net revenue/rabbit (L.E) & 16. in 26 & 16.36 & 16.94 \\
Economic efficiency (E.E) & 69.58 & 70.30 & 71.00 \\
Relative E. E (\%) & 100 & 101.03 & 102.04 \\
\hline
\end{tabular}

${ }^{*}$ Treatments, $T_{0}$ Control, containing no MOLM;

$T_{3}=$ Containing 3\% MOLM; $T_{6=}$ Containing 6\% MOLM.

** According to price of feed ingredients during the experimental period (2017).

And price of Moringa oleifera leaves meal $=4200$ L.E/ ton. 


\section{Bakr et al.}

\section{CONCLUSION}

It could be concluded from the present results that Moringa oleifera leaves meal (MOLM) can be used up to $6 \%$ the rabbit's diets as an untraditional source of protein without any adverse effects on growth performance, carcass traits and physiological status.

\section{REFERENCES}

AOAC (2012) Association of Official Analytical Chemists. Official methods of analysis. 19th Ed. AOAC, Washington. DC, USA.

Abdel-Azeem, A. F.; F. A. Mohamed; S. E. M. EL-Shiekh and A. F. Hessin (2017). Maximizing productivity of Lohmann chickens by feeding diets inclusions different levels of Moringa oleifera leaf meal as a safe feed additive. J. Animal and poultry prod. Mansoura University, 8 (8): 319-328.

Abo EL-Azab, Q. M. M. (2015). Effect of some natural antioxidants supplementation on productive performance of rabbits under heat stress conditions. Ph. D thesis,. Department of poultry production. Faculty of Agriculture, Ain Shams University.

Aboul-ELa, S. S.; F. A. F. Ali; A. Madi and M. R. A. Abdel-Naby (2011). Olive cake meal as partial or complete substitute for clover hay in growing rabbit diets. Egyptian Journal of Nutrition and Feeds, 14: 109-119.

Abo-Zaid, M. A.; S. E. A. Farag and M. Saad (1993). Identification and purification of the phenolic compounds extracted from olive cakes. Egyptian Journal of Applied Science, 8 (6): 791-802.

Abubakar, M; U. Ibrahim; A. U. Yusuf; A. S. Muhammad and N. Adamu (2015) Growth performance, Carcass and organ characteristics of growing rabbits fed graded leaves of Moringa oleifera leaf meal in diets. Bayera Journal of pure and Applied Sciences, 8 (2): 7-9.

Adedapo, A. A.; O. M. Moghojuri and B. O. Emikpe (2009). Safty evaluations of aqueous extract of leaves of Moringa oleifera in rats. Journal of Medicinal Plants Research, 3 (8): 586-591.

Agriculture Ministry Decree (1996). The Standard Properties for Ingredients, Feed Additives and Feed Manufactured for Animal and Poultry. El-Wakaee.

Ahemen, T.; A. H Abu and L. K. Iorgilim (2013). Physiological responses of rabbits fed graded levels of Moringa oleifera leaf meal (MOLM): Some aspects of hematology and serum biochemistry Archives of Applied Science Research, 5 (2): 172 - 176.

Ahmed, R. M. A. (2017). Evaluation of Moringa (Moringa oleifera) as a new feed for rabbits, M. Sc. Thesis, Department of Animal and Poultry production, Faculty of Technology and development. Zagazig University.

Akinmutimi, A. H. (2004). Evaluation of Sword bean (Canavalia gladiate) as an alternative feed resources for broiler. Department of Non-ruminant Animal prod, Ph. D thesis. Michael Okpara University of Agriculture, Umudike, Nigeria.

Bouatene, D; L. G. Bohoua and S. Dabonne (2011). Effect of Moringa oleifera on growth performance and health status of young post-weaning rabbits. Research Journal of Poultry Sciences, 4 (1): 7-13.

Cheeke, P. R. (196). Potentials of rabbit production in tropical and subtropical agricultural systems. J. Ani. Sci. 63,1581-1586.

Cheeke, P. R. (1987). Rabbit feeding and nutrition. Academic press. Ozlanda, Florida, U. S. A.

Dacie, J. V. and S. M. Lewis (1995). Practical hematology. $8^{\text {th }}$ ed. Churchill Livingstone, Edinburgh.

Dong, X. F.; W.W. Gao; J.M. Tong; H. Q. Jia; R. N. Sa and Q. Zhang (2007). Effect of palysavane (alfalfa extract) on abdominal fat deposition and Immunity in broiler chekens. Poult. Sci., 86: 19951959.

DU, P. L.; P. H. Lin; R.Y. Yang and J. C. Hsu (2007). Effect of dietary supplementation of Moringa oleifera on growth performance, blood characteristics and immune response in broilers. Journal of chinese society of Animal Science, 36 (3): 135-146. 
Duke, J. A. (1983). Handbook of energy crops (Moringa oleifera). Center for new crops and plant products. Purdue University, Indiana, US. http: www. hort.

Emongor,V. E. (2009). Growth of Moringa (Moringa oleifera lam) seedling provenances under Batswana conditions. Botswana of Agricultural and Applied Science, 5 (2): 56-63.

Esonu, B. O; C. F. Ekpor; I. C. Okoli and F. C. Iheukwumere (2001). Performance and blood chemistry of weaner pigs fed raw mucuna (velvet bean) meal. Tra. Anim. Prod. Invest, 4: 49-54.

Foidl, N. and R. Paull (2008). Moringa oleifera. In: the Encyclopedia of fruit and nutrient (ABI, Oxford shine. UK, Pp 509-512.

Fuglie, L(1999). Proceeding food without pesticides: local solution to crop pest control in west Africa CTA. Wageningen the Nether lands.

Hewitt, C. D.; D. J. Innes; J. Savary and M. R. Wills (1989). Normal biochemical and hematological values in New Zealand white rabbits. Clin. Chem., 35 (8): 1777 - 1779.

Iheukwumere, F. C. and I. C. Okoli (2002). Preliminary studies on raw Napoleana Imperialis as feed ingredient. 1: performance and blood chemistry of weaner rabbits. Trop-Anim. Prod., 5: 100-110.

Kelly, S. A. (2009). Moringa oleifera a multipurpose tree: Amandla resources. Ph. D. Dissertation, Kwazulu- Natal University, South Africa.

Makkar, H. P. S and K. Becker (1997). Nutrients and antiquity factors in different morphological parts of Moringa oleifera tree. J. Agri. Sci., 128: 311-322.

Manning, P. J.; D. H. Ringler and C. E. New comer (1994). The Biology of Laboratory Rabbit, $2^{\text {nd }}$ ed. Academic press inc., San Diego, California, USA.

MOA (2001). Feed composition tables for Animal and Poultry feed stuff used in Egypt. Technical Bulletin No.1, central Lab for feed and food, Ministry of Agriculture, Egypt.

Nuhu, F. (2010). Effect of Moringa leaf meal (MOLM) on nutrient digestibility growth, carcass and blood indices of weaner rabbits. M. SC. Thesis, faculty of Agriculture of Science and Natural resources, Kwame Nkrumah University of science and Technology, Kumasi.

Odetola, O.; O. Adetola; T. I. OIjadunala; O. Y. Adedeji and O. A. Adu (2012). Utilization of moringa (Moringa oleifera) leaves meal as replacement for soybean meal in rabbits diets. Scholarly Journal of Agricultural Science, 2 (12): 309 - 313.

Odeyinka, S. M.; O. J. Oyedele; T. O. Adeleke and J. A. Odedire (2008). Reproductive performance of rabbits fed Moringa oleifera as replacement for centrosema Pubescens, gth world rabbit congress, Verona. Italy.

Omara, M. E., EL-Esawy Ghadas; W. A. Riad and A. M. A. Mohi EL-Din (2017). Effects of supplementing rabbits diets with Moringa oleifera dry leaves as different levels and their produdive performance Academia Journal of Biotechnology, 5 (1).

Oyawoye, E. O. and M. Ogunkunle (1998). Physiological and biochemical effects of raw jack beans on broilers. Proceeding of annual conference of Nigerian Society of Animal production, 23: 141-142.

Ozovehe, B. N. and G. C. Nzeh (2013). Effect of varying of Moringa oleifera leaf meal diet on growth performance, hematological indices and biochemical enzymes of African catfish (Clarias gariepinus). Elixir Aquaculture 57A: 14459 - 14466.

SAS Institute Inc., (2004). SAS procedures Guide for personal computers, Statistical Analysis System Institute, Inc., Cary, N. C.

Shetaewi, M. M. (1998) Efficacy of Dietary High Levels of Antioxidant Vitamins C And E for Rabbits Subjected to Crowding Stress. Egyptian J. Rabbit Sci., 8 (2): 95-112

Sravanthi, J. and S. G. Rao (2014) Anti-oxidative studies in Moringa oleifera Lam. Annals of phytomedicine, 3 (2): $101-105$.

Steel, R. G. D. and J. H. Torrie (1980). Principles and Procedures of Statistics: A Biometrical Approach $\left(2^{\text {nd }}\right.$ Ed.). Mc Graw-Hill Book Co., New York.

Thrall, M. A.; G. Weiser; R. Allison and T. W. Compbell (2012). Veterinary Hematology and clinical chemistry. $2^{\text {nd }}$ ed. Wiley-Blackwell, John Wiley \& Sons, Inc. Ames, IA, USA. 


\title{
Bakr et al.
}

Wintrobe (1967). Clinical Hematology $6^{\text {th }}$ Ed Lea and Febiger, Philadelphia, $415-427$.

Yakubu, B; J. M. Nathan and M. S. Yahya (2013). Effects of substituting ground nut cake with moringa (Moringa oleifera) leaf meal on growth performance, carcass yield and hematological profile of weaner rabbits. Journal of Science, Technology \& Education, 2, (1): 77-84.

Yang, R. X; S. C. S Tsou; T. C Lee; L. C Chang; G. Kuo and P. Y. Lai (2006). Moringa a novel plant nutrients. American Chemical Society Symposium Series, 925: 224-239.

الأداء الإنتاجى والتغيرات البيوكيميائية للأرانب المغذاة على مسحوق أوراق المورينجا كمصدر غير تقليدى

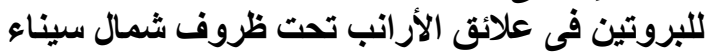

\author{
السيد عثمان عبدالنبى بكر , عبدالثافى محم عبدالسميع ومسعد مسعد شتيوى

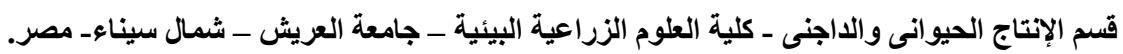

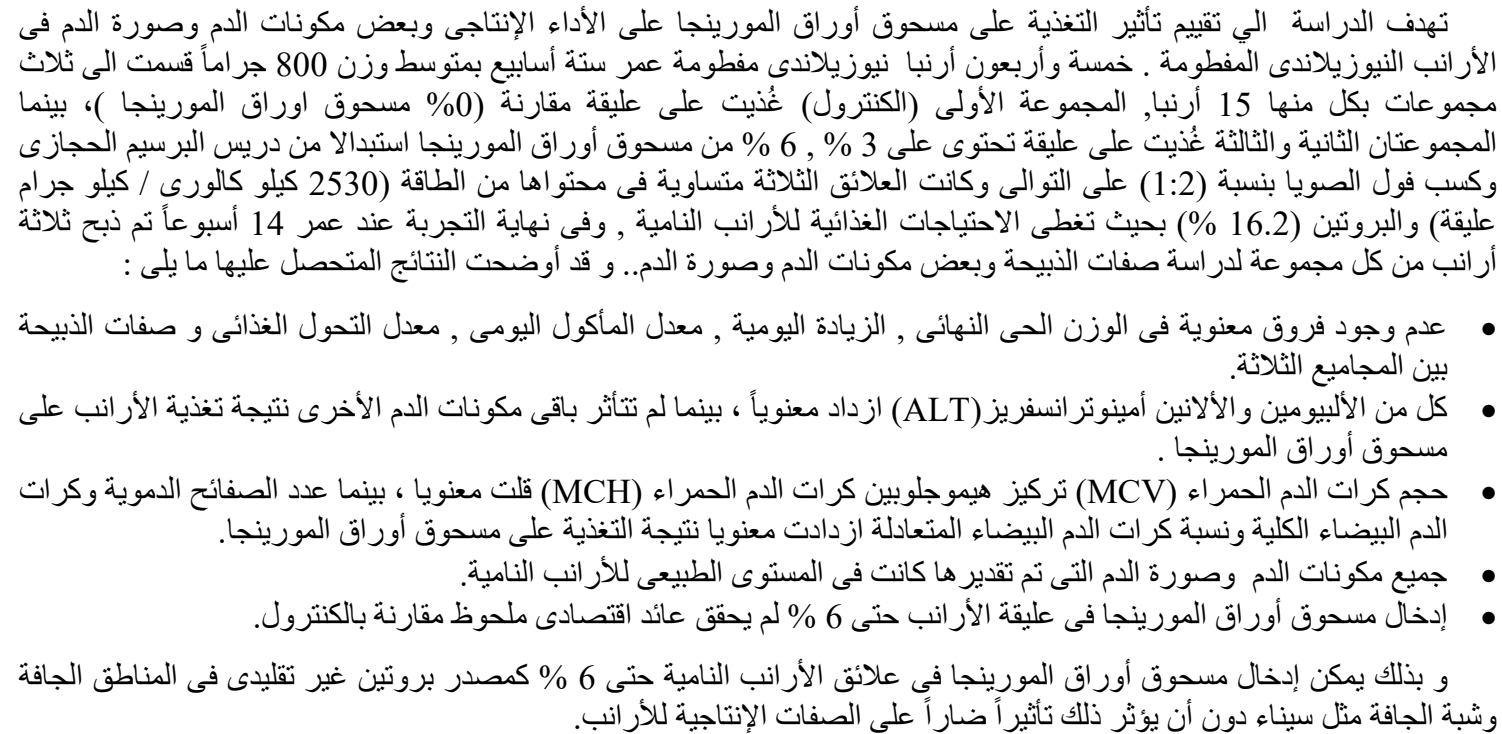

